\title{
BAGAIMANA PRAKTIK MANAJEMEN LABA DAN PENGHINDARAN PAJAK SEBELUM DAN SETELAH PANDEMI COVID19 DI INDONESIA?
}

\author{
Amrie Firmansyah ${ }^{1}$ \\ ${ }^{1}$ Jurusan Akuntansi, Politeknik Keuangan Negara STAN \\ Risanto Ardiansyah ${ }^{2}$ \\ 2Jurusan Akuntansi, Politeknik Keuangan Negara STAN
}

\begin{abstract}
This study investigates the difference between tax avoidance and earnings management, consisting of accrual earnings management and real earnings management. Also, this study investigates the association between accrual earnings management and real earnings management with tax avoidance in the pandemic era. The research data is sourced from financial reports of consumers goods industry companies listed on the Indonesia Stock Exchange from 2019 to 2020, obtained from www.idx.co.id. Based on purposive sampling, the total sample in this study amounted to 74 observations. Hypothesis testing in this study employed paired sample t-test or Wilcoxon NonParametric Test to examine the comparative hypothesis and multiple regression analysis for crosssection data to examine the correlative hypothesis. This study suggests no difference in tax avoidance, accrual earnings management, real earnings management level in the pandemic era compared to the pra-pandemic era. This study also concludes that real earnings management is negatively associated with tax avoidance during the pandemic, while accrual earnings management is not associated with tax aggressiveness. The Indonesia Tax Authorities need to improve monitoring and control procedures related to tax avoidance activities conducted by companies.
\end{abstract}

Keywords: accrual earnings management; pandemic era; real earnings management; tax avoidance.

\begin{abstract}
ABSTRAK
Penelitian ini bertujuan untuk menginvestigasi perbedaan penghindaran pajak dan manajemen laba yang terdiri dari manajemen laba akrual dan manajemen laba riil. Selain itu, penelitian ini juga menguji pengaruh manajemen laba akrual dan manajemen laba riil terhadap penghindaran pajak di era pandemi. Data penelitian ini bersumber dari laporan keuangan perusahaan industri barang konsumsi yang terdaftar di Bursa Efek Indonesia periode 2019 hingga 2020, yang diperoleh dari www.idx.co.id. Berdasarkan purposive sampling, jumlah sampel dalam penelitian ini berjumlah 74 observasi. Pengujian hipotesis dalam penelitian ini menggunakan paired sample t-test atau Wilcoxon Non-Parametric Test untuk menguji hipotesis komparatif dan analisis regresi berganda untuk data cross-section untuk menguji hipotesis korelatif. Penelitian ini menunjukkan bahwa tidak ada perbedaan tingkat penghindaran pajak, manajemen laba akrual, manajemen laba riil di era pandemi dibandingkan dengan era pra-pandemi. Penelitian ini juga menyimpulkan bahwa manajemen laba riil berhubungan negatif dengan penghindaran pajak selama era pandemi, sedangkan manajemen laba akrual tidak berhubungan dengan agresivitas pajak. Penelitian ini mengindikasikan bahwa Otoritas Pajak Indonesia perlu meningkatkan prosedur pengawasan dan pengendalian terkait kegiatan penghindaran pajak yang dilakukan oleh perusahaan.
\end{abstract}

Kata kunci: manajemen laba akrual; masa pandemi; manajemen laba riil; penghindaran pajak Klasifikasi JEL: M40; M41; G38

\section{PENDAHULUAN}

Lebih dari satu tahun Pandemi Covid-19 melanda Indonesia, selain menyebabkan krisis kesehatan pandemi ini juga memicu terjadinya krisis ekonomi yang bahkan berujung resesi (Asmara, C. G., 2020). Pemerintah telah melakukan banyak upaya agar ekonomi negara tidak 


\section{3 | Bina Ekonomi}

semakin terpuruk (Rahma Nidya, 2020). Salah satunya adalah peningkatan kegiatan ekonomi dengan cara pemberian stimulus kepada masyarakat berupa program insentif perpajakan kepada pelaku usaha (Kementerian Keuangan RI, 2020). Program yang merupakan bagian dari Pemulihan Ekonomi Nasional (PEN) ini terdiri dari penurunan tarif PPh Badan sesuai dengan Pasal 5 ayat (1) Perppu nomor 1 Tahun 2020 dan Insentif perpajakan seperti pembebasan PPh 22 impor dan pengurangan angsuran PPh 25 sesuai dengan PMK 23 Tahun 2020 sebagaimana telah beberapa kali diubah terakhir dengan PMK 110 Tahun 2020.

Perusahaan merespon dengan baik atas insentif ini, sesuai dengan paparan Menteri Keuangan tanggal 25 November 2020 yang menyatakan bahwa lebih dari 451.026 perusahaan sudah mengajukan permohonan insentif pajak dan sebanyak 214.097 permohonan telah disetujui oleh Kementerian Keuangan (Nordiansyah, 2020). Atas pemberian insentif ini, selama tahun 2020 Pemerintah mengeluarkan dana sebesar 56,12 Triliun Rupiah atau terealisasi sekitar 46,51 persen dari alokasi anggaran yang disediakan sebesar 120,61 triliun rupiah (Fathimah Timorria, 2021) . Kebijakan pemerintah terkait dengan perpajakan ini diharapkan dapat mengurangi beban perusahaan dan dapat membantu arus kas perusahaan selama periode pandemi.

Pemberian insentif ini dapat direspon oleh manajer perusahaan untuk melakukan praktik penghindaran pajak selama periode pandemi. Pajak penghasilan dalam porsi yang signifikan akan mengurangi sebagian dari laba yang telah diperoleh perusahaan (Pipatnarapong et al., 2020). Selain itu, meminimalisir utang pajak juga termasuk dalam rangka memaksimalkan nilai perusahaan selama manfaatnya melampaui biayanya (Desai \& Dharmapala, 2009), pihak pemilik perusahaan pun akan mendorong manajemen untuk mengurangi beban pajak yang timbul dengan melaksanakan agresivitas pajak (Chen et al., 2010).

Selain motivasi internal dari perusahaan untuk melakukan tindakan penghindaran pajak, pemberian insentif perpajakan dapat menjadi sarana dalam melakukan tindakan penghindaran pajak yang dilakukan oleh manajer. Selain itu, selama pandemi dapat menurunkan pengawasan yang menjadi faktor penyebab terjadinya penghindaran pajak (Rayahu, 2010). Penurunan pengawasan ini selama kondisi pandemi karena kegiatan-kegiatan pelayanan perpajakan banyak dilakukan dengan aktivitas work from home sehingga proses kontrol pemberian stimulus perpajakan akan menurun, terlebih lagi jumlah permohonan stimulus yang sangat tinggi serta persetujuan atas permohonan pemberian stimulus yang diharapkan dapat diselesaikan dalam waktu sesingkat mungkin. Oleh karena itu, aktivitas penghindaran pajak dan manajemen laba perlu diinvestigasi lebih lanjut khususnya terkait dengan pandemi covid19.

Penelitian yang menguji penghindaran pajak telah banyak dilakukan dalam penelitian sebelumnya. Di level internasional, penghindaran pajak diuji dengan menggunakan manajemen laba (Desai \& Dharmapala, 2009; Wang \& Chen, 2012; Pipatnarapong et al., 2020), enterprise risk management (Eastman et al., 2020) directors connected to a tax office (Zhao et al., 2020), external audit firm (McGuire et al, 2012), corporate social responsibility (Huseynov \& Klamm, 2012; Liu \& lee,2019), nilai perusahaan (Desai \& Dharmapala, 2009). Arham et al. (2020) telah menginvestasi pengujian penghindaran pajak yang dilakukan dengan menggunakan data Indonesia. Beberapa pengujian terhadap penghindaran pajak dilakukan dengan menggunakan manajemen laba (Nugroho \& Firmansyah, 2017; Ferdiawan \& Firmansyah, 2017; Pratama, 2020; Tiaras \& Wijaya, 2017), likuiditas (Dewi \& Cynthia, 2018; Ardy \& Kristanto, 2015; Suyanto \& Supramono, 2012; Tiaras \& Wijaya, 2015), leverage (Nurhandono \& Firmansyah, 2017; Turyatini, 2017; Suyanto \& Supramono, 2012), ukuran perusahaan (Turyatini, 2017; Harnovinsah \& Septyana, 2016; Tandean, 2016; Dewi \& Cynthia, 2018), kepemilikan institusional (Hanna \& Haryanto, 2017; Tandean,2016; Turyatini, 2017), komisaris independen (Sandy \& Lukviarman, 2015; Maraya \& 
Yendrawati, 2016; Turyatini, 2017), kualitas audit dan ukuran KAP (Sandy \& Lukviarman, 2015; Maraya \& Yendrawati, 2016; Saputra et al., 2015), komite audit (Tandean, 2016; Hanna \& Haryanto, 2016; Sandy \& Lukviarman, 2015), kepemilikan manajerial (Maraya \& Yendrawati, 2016), corporate governance (Gunawan, 2017), bankruptcy risk (Nurfauzi \& Firmansyah, 2018), lindung nilai (Nurhandono \& Firmansyah, 2017), kepemilikan keluarga (Hidayati \& Diyanty, 2018; Hanna \& Haryanto, 2017; Ardy \& Kristanto, 2015), corporate social responsibility (Maraya \& Yendrawati, 2016; Gunawan, 2017; Dewi \& Cynthia, 2018), pemanfaatan tax heaven countries (Damayanti \& Prastiwi, 2017; Falbo \& Firmansyah, 2018).

Penghindaran pajak merupakan salah satu kebijakan manajemen dalam perencanaan pajak (Hanlon \& Heitzman, 2010). Kebijakan penghindaran pajak erat kaitannya dengan kebijakan manajemen lainnya seperti kebijakan akuntansi, karena jumlah pajak yang dibayar perusahaan dipengaruhi jumlah pendapatan sebelum pajak yang dilaporkan oleh perusahaan. Selain itu, adanya diskresi manajer terkait dengan informasi angka-angka akuntansi mengakibatkan manajer memiliki kesempatan untuk melakukan manajemen laba. Disisi lain, pembayaran pajak yang rendah seharusnya didapat dari pendapatan sebelum pajak yang rendah pula. Hal ini tentu saja akan bertentangan dengan keinginan pemilik perusahaan yang menginginkan pendapatan setinggi-tingginya. Nugroho \& Firmansyah (2017) menyatakan bahwa perusahaan dapat menggunakan manajemen laba untuk menaikkan laba bersih dengan diikuti turunnya penghasilan kena pajak perusahaan. Hal ini sejalan dengan pernyataan Frank et al. (2004) bahwa manajemen laba untuk tujuan fiskal dan komersial dapat dilakukan bersamaan. Hasil penelitian yang sejalan juga ditemukan oleh Geraldina (2013) yang menyimpulkan bahwa perusahaan yang melakukan manajemen laba akan meningkatkan kemungkinan perusahaan untuk melakukan kegiatan tax shelter, atau dapat diduga perusahaan yang melakukan manajemen laba intensif juga melakukan penghindaran pajak yang agresif (Ferdiawan \& Firmansyah, 2017).

Dalam melaksanakan manajemen laba, perusahaan dapat menggunakan dua metode yaitu manajemen laba akrual dan manajemen laba riil. Badertscher (2011) menyatakan bahwa manajemen laba akrual dapat dilaksanakan dengan menyesuaikan pendapatan atau biaya akrual untuk mengubah laporan keuangan. Cara ini cukup populer karena dapat dilakukan pada akhir periode setelah laba pra-akrual diketahui dan dapat dilaksanakan dalam batasan-batasan yang diatur dalam standar akuntansi keuangan. Opsi manajemen laba riil secara sengaja dilakukan oleh manajer untuk mengubah laba dalam laporan keuangan dengan mengubah waktu dan struktur dari keputusan operasi, investasi, atau pendanaan. Kelebihan dari metode ini dibanding dengan metode akrual adalah sulit dideteksi oleh auditor atau pemerintah. Di Amerika Serikat setelah penerapan Sarbanes-Oxley Act penggunaan manajemen laba akrual mengalami penurunan, sedangkan penggunaan manajemen laba riil meningkat secara signifikan (Badertscher, 2011).

Beberapa penelitian sebelumnya telah menguji pengaruh manajemen laba terhadap agresivitas pajak, namun masih memperlihatkan adanya inkonsistensi hasil pengujiannya. Pratama (2020), Machdar (2019), Tiaras \& Wijaya (2015) dan, Suyanto \& Supramono (2012) menemukan bahwa manajemen laba akrual berpengaruh positif terhadap penghindaran pajak. Hasil berbeda ditemukan oleh Simamora (2017) menyatakan bahwa manajemen laba akrual tidak berpengaruh terhadap agresivitas pajak. Selain itu, Machdar (2019) menyimpulkan bahwa manajemen laba riil berpengaruh positif terhadap penghindaran pajak. Nugroho \& Firmansyah (2017) juga menyimpulkan temuan yang sama, namun hanya untuk manipulasi penjualan, sedangkan manajemen laba riil melalui manipulasi produksi dan manipulasi beban diskresioner memiliki pengaruh yang berkebalikan. Hasil yang berbeda ditemukan Ferdiawan \& Firmansyah (2017) dan Simamora (2017) bahwa manajemen laba riil tidak berpengaruh terhadap agresivitas pajak. Adanya kemungkinan insentif pajak digunakan oleh perusahaan untuk melaksanakan 


\section{5 | Bina Ekonomi}

manajemen laba dengan tujuan penghindaran pajak dan masih terdapatnya perbedaan hasil penelitian pengaruh manajemen laba akrual dan manajemen laba riil terhadap penghindaran pajak perlu adanya pengujian kembali dalam penelitian ini.

Penelitian ini bertujuan untuk menguji manajemen laba akrual dan manajemen laba riil terhadap penghindaran pajak pada era pandemi. Selain itu, penelitian ini menguji perbedaan praktik manajemen laba akrual, manajemen laba riil, penghindaran pajak sebelum dan selama era pandemi. Penelitian ini menggunakan data perusahaan sektor consumer goods industry karena merupakan salah satu sektor yang terbanyak memanfaatkan insentif pajak (Kusuma, 2020). Penelitian ini berbeda dengan penelitian sebelumnya karena dalam penelitian ini membandingkan tingkat praktik manajemen laba baik akural maupun riil dan penghindaran pajak dalam periode berbeda, dimana penelitian sebelumnya hanya membandingkan manajemen laba akrual saja seperti Azizah (2021) dan penghindaran pajak seperti Suhaidar et al. (2021), sedangkan penelitian ini membandingkan tingkat pengaruh manajemen laba akrual, manajemen laba riil dan penghindaran pajak dalam periode sebelum dan pandemi covid19. Penelitian Simamora (2017), Machdar (2019), dan Pipatnarapong et al. (2020) menguji manajemen laba terhadap agresivitas pajak pada periode tertentu, sedangkan penelitian ini menguji manajemen laba akrual dan riil terhadap penghindaran pajak dalam periode pandemi covid19.

Penelitian ini diharapkan dapat memberikan kontribusi dalam penelitian bidang akuntansi keuangan khususnya praktik manajemen laba dan hubungannya dengan agresivitas pajak di era pandemi. Hasil penelitian ini juga diharapkan dapat memberikan saran perbaikan kebijakan dibidang perpajakan khususnya Direktorat Jenderal Pajak, Kementerian Keuangan dalam mengambil keputusan yang berhubungan dengan pemberian insentif pajak, audit pengguna jasa, atau pencapaian target penerimaan pajak.

Dalam teori keagenan, manajemen selaku agen dituntut untuk dapat memenuhi kepentingan prinsipal seperti menjaga kondisi perusahaan serta tetap mencapai target laba selama periode pandemi. Untuk mencapai kepentingan prinsipal ini agen diberikan otoritas dan kewenangan pengambilan keputusan dalam menjalankan perusahaan (Jensen \& Meckling, 1976). Namun, adanya perbedaan kondisi ekonomi selama masa pandemi memaksa manajer selaku agen untuk melakukan upaya ekstra untuk memenuhi kepentingan prinsipal. Bahkan manajer akan menggunakan teknik manajemen laba akrual demi mencapai laba yang ditargetkan, karena manajemen laba dapat digunakan sesuai dengan tujuan spesifik yang diinginkan termasuk income maximization (Scott, 2015).

Penggunaan manajemen laba didukung dengan motivasi keuntungan pribadi manajemen perusahaan berupa bonus jika target laba tercapai (Scott, 2015). Selain itu, adanya informasi asimetri akibat hubungan antara agen dan prinsipal serta kewenangan yang diberikan oleh prinsipal untuk menjalankan perusahaan termasuk pemilihan kebijakan akuntansi dapat menjadi alat dan kesempatan untuk melakukan tindakan manajemen laba akrual. Azizah (2021) menemukan perbedaan tingkat manajemen laba akrual pada Q1 periode pandemi dimana nilainya lebih rendah dibandingkan dengan Q1 pada periode sebelum pandemi. Selain itu penggunaan manajemen laba akrual cukup populer digunakan oleh Perusahaan di Indonesia bahkan setelah penerapan IFRS Tahun 2012 (Firmansyah \& Irawan, 2018).

Kondisi ekonomi yang tidak menentu selama masa pandemi memaksa manajer selaku agen harus melakukan upaya ekstra termasuk manajemen laba demi mencapai laba yang ditargetkan. Selain itu Tindakan oportunistik manajemen, adanya informasi asimetri, serta pemberian otoritas berupa diskresi manajer atas kebijakan akuntansi tertentu pada laporan 
keuangan dapat diduga ada peningkatan praktik manajemen laba akrual pada periode pandemi. Oleh karena itu, hipotesis pertama dalam penelitian ini adalah sebagai berikut:

$\mathrm{H}_{1}$ : Terdapat Perbedaan tingkat manajemen laba akrual sebelum dan setelah masa pandemi

Selain pemilihan kebijakan akuntansi, manajemen perusahaan selaku agen juga mendapat otoritas terkait kegiatan operasi riil perusahaan. Dengan adanya informasi asimetri antara prinsipal dan agen, manajemen perusahaan dapat menggunakan otoritas ini untuk melakukan manajemen laba riil dengan cara merubah waktu atau struktur operasi, investasi atau pendanaan (Zang, 2011) atau bahkan dengan melakukan kegiatan yang menyimpang dari aktivitas operasi normal (Cohen \& Zahrowin, 2010). Namun, kondisi pandemi menuntut manajemen perusahaan beradaptasi termasuk dalam kegiatan manajemen laba. Manajemen dapat melakukan manipulasi Beban Diskresioner melalui penundaan pelatihan pegawai dengan alasan mentaati peraturan Pembatasan Sosial Berskala Besar (PSBB) yang dimulai sejak Bulan April 2020.

Selain itu sesuai dengan Zang (2011) manajemen dalam memilih metode manajemen laba mempertimbangkan biaya relatif dari metode tersebut, dimana salah satu biaya relatif dari manajemen laba riil adalah peningkatan beban pajak. Namun, dengan adanya insentif perpajakan berupa turunnya tarif pajak selama pandemi manajemen dapat lebih leluasa dalam menggunakan metode manajemen laba riil. Manipulasi laba melalui metode manajemen laba riil juga memiliki keunggulan, yaitu lebih sulit untuk dideteksi (Cohen et al., 2007),

Selain menggunakan manajemen laba akrual, untuk menyiasati tercapainya tujuan manajemen perusahaan, baik dalam mencapai target laba perusahaan maupun tujuan oportunistik pribadinya pada periode pandemi, manajer menggunakan alternatif lain yaitu manajemen laba riil. Manajemen laba riil memiliki keunggulan lebih sulit dideteksi oleh auditor dan otoritas perpajakan. Dengan adanya insentif berupa penurunan tarif pajak maka biaya penerapan manajemen laba riil ini dapat diminimalisasi. Oleh karena itu, praktik manajemen laba riil diduga mengalami peningkatan selama periode pandemi, sehingga hipotesis kedua dalam penelitian ini adalah sebagai berikut:

$\mathrm{H}_{2}$ : Terdapat Perbedaan tingkat manajemen laba riil sebelum dan setelah masa pandemi

Dengan adanya insentif perpajakan yang dikeluarkan oleh Pemerintah Indonesia, terdapat adanya resiko meningkatnya penghindaran pajak yang dilakukan oleh perusahaan. Perusahaan dapat memanfaatkan peraturan perpajakan termasuk insentif perpajakan untuk melakukan penghindaran pajak (Zain, 2008). Motivasi penghindaran pajak dapat timbul dari internal perusahaan karena perusahaan menganggap pajak sebagai beban dan dalam porsi yang signifikan akan mengurangi sebagian dari laba yang telah diperoleh perusahaan (Pipatnarapong et al., 2020). Pemilik perusahaan akan mendorong manajemen untuk mengurangi beban pajak yang timbul dengan melakukan penghindaran pajak (Chen et al., 2010).

Selain motivasi internal dari perusahaan untuk melakukan tindakan penghindaran pajak, proses kontrol atau pengawasan pemberian stimulus perpajakan yang menurun akibat pelaksanaan kegiatan work from home selama pandemi dihadapi dengan jumlah permohonan stimulus yang sangat tinggi serta persetujuan atas permohonan pemberian stimulus yang diharapkan dapat diselesaikan dalam waktu sesingkat mungkin akan meningkatkan kemungkinan terjadinya resiko penghindaran Pajak pada masa pandemi (OECD, 2020). Suhaidar et al. (2021) menemukan terdapat perbedaan penghindaran pajak berupa naiknya tingkat penghindaran pajak selama periode Covid-19 dibandingkan sebelum periode Covid-19. Penelitian 


\section{7 | Bina Ekonomi}

tersebut juga menyimpulkan bahwa peningkatan penghindaran pajak dapat terjadi karena pemberian insentif perpajakan mendorong peluang bagi manajer untuk menyalahgunakan kewajiban perpajakan.

Adanya pemberian insentif berupa penurunan tarif pajak dapat digunakan oleh manajemen perusahaan untuk melakukan Tindakan penghindaran Pajak. Kondisi ini didukung oleh motivasi internal perusahaan yang menganggap pajak sebagai beban dan dapat mengurangi laba dalam porsi yang cukup signifikan ditambah dengan adanya dorongan dari pihak pemegang saham untuk melakukan tindakan penghindaran pajak untuk meningkatkan nilai perusahaan (Irawan \& Turwanto, 2020). Selain itu, selama pandemi tingkat kontrol dan pengawasan atas pemberian insentif perpajakan kemungkinan mengalami penurunan. Oleh karena itu, praktik penghindaran pajak selama periode pandemi menjadi meningkat, sehingga hipotesis ketiga dalam penelitian ini adalah sebagai berikut.

$\mathrm{H}_{3}$ : Terdapat perbedaan tingkat penghindaran pajak sebelum dan setelah masa pandemi

Salah satu bentuk informasi asimetri yang dimanfaatkan oleh manajer adalah tindakan penghindaran pajak. Perusahaan memiliki motivasi untuk melakukan penghindaran pajak karena pajak penghasilan dalam porsi yang signifikan akan mengurangi sebagian dari laba yang telah diperoleh perusahaan (Pipatnarapong et al, 2020), namun pembayaran pajak yang rendah seharusnya dihasilkan dari pendapatan sebelum pajak yang rendah. Hal ini tentu saja akan bertentangan dengan keinginan pemilik pemilik perusahaan untuk mendapatkan pendapatan setinggi-tingginya.

Nugroho \& Firmansyah (2017) menyatakan bahwa perusahaan dapat menggunakan manajemen laba untuk menaikkan laba bersih dengan diikuti turunnya penghasilan kena pajak perusahaan. Hal ini sejalan dengan pernyataan Frank et al (2004) bahwa manajemen laba untuk tujuan fiskal dan komersial dapat dilakukan bersamaan. Geraldina (2013) menyimpulkan bahwa perusahaan yang melakukan manajemen laba akan meningkatkan kemungkinan perusahaan untuk melakukan kegiatan tax shelter, atau dapat diduga perusahaan yang melakukan manajemen laba intensif juga melakukan penghindaran pajak yang agresif (Ferdiawan \& Firmansyah, 2017).

Dalam melakukan tindakan manajemen laba ini manajemen didukung oleh beberapa hal yaitu adanya asimetri informasi dimana manajemen selaku agen lebih mengetahui kondisi perusahaan dibandingkan dengan prinsipal. Selain itu pemberian kewenangan dan otoritas oleh prinsipal kepada manajemen perusahaan selaku agen berupa keleluasaan dalam memilih kebijakan akuntansi dapat digunakan oleh manajemen untuk melakukan Tindakan manajemen laba akrual untuk tujuan tertentu termasuk penghindaran pajak. Hal ini sejalan dengan Pajriyansyah \& Firmansyah (2017), Surahman \& Firmansyah (2017), dan Machdar (2019) yang menemukan bahwa manajemen laba akrual merupakan strategi manajer untuk melakukan penghindaran pajak.

Adanya insentif perpajakan yang diberlakukan oleh pemerintah mengakibatkan intensi manajemen perusahaan untuk melakukan penghindaran pajak yang semakin tinggi. Untuk melakukan penghindaran pajak, manajer dapat menggunakan praktik manajemen laba akrual melalui diskresi manajer atas kebijakan akuntansi tertentu pada laporan keuangan. Oleh karena itu, hipotesis keempat dalam penelitian ini sebagai berikut:

$\mathrm{H}_{4}$ : Manajemen laba akrual memiliki pengaruh positif terhadap penghindaran pajak

Adanya masalah keagenan mengakibatkan manajer tetap mencari celah untuk melakukan 
aktivitas manajemen laba untuk motif-motif tertentu. Meskipun manajemen laba riil memiliki kelebihan lebih sulit untuk dideteksi oleh auditor atau otoritas perpajakan (Cohen et al., 2008), penggunaan manajemen laba riil masih masih belum sepopuler manajemen laba akrual bahkan setelah penerapan standar akuntansi IFRS di Indonesia karena perusahaan masih dengan leluasa untuk menggunakan manajemen laba akrual akibat rendahnya pengawasan pemangku kepentingan (Firmansyah \& Irawan, 2018). Selain itu, terdapat biaya yang harus ditanggung oleh perusahaan jika memilih untuk menggunakan manajemen laba riil yaitu meningkatnya beban pajak pada periode saat ini (Zang, 2012).

Pemilik perusahaan memberikan kewenangan kepada manajemen perusahaan, termasuk kewenangan dalam menjalankan operasi perusahaan. Dalam pelaksanaannya, manajer memiliki informasi yang lebih sempurna atas kondisi keuangan perusahaan dibandingkan pemegang saham, sehingga kondisi asimetri informasi juga dapat digunakan manajemen untuk melakukan manajemen laba. Manajemen dapat menggunakan manajemen laba riil untuk tujuan yang ingin dicapai, baik demi mengejar tujuan oportunistik pribadi maupun untuk tujuan penghindaran pajak. Beberapa penelitian sebelumnya mendapatkan bukti bahwa manajemen laba riil memiliki pengaruh terhadap penghindaran pajak. Surahman \& Firmansyah (2017), Machdar (2019), Nugroho \& Firmansyah (2017) menemukan bahwa manajemen laba riil digunakan oleh manajer untuk melakukan penghindaran pajak. Walaupun di Indonesia terdapat kecenderungan manajemen laba riil belum terlalu banyak digunakan sebagaimana manajemen laba akrual, namun manajer berusaha untuk melakukan manajemen laba yang kecil kemungkinannya dapat dideteksi oleh auditor dan otoritas perpajakan di Indonesia.

Pemerintah memberikan insentif perpajakan kepada perusahaan dalam kondisi pandemi covid19. Kondisi tersebut dapat dimanfaatkan oleh manajer untuk mendapatkan keuntungan dari perencanaan perpajakan melalui tindakan manajemen laba riil. Tindakan manajemen laba riil merupakan salah satu alternatif yang digunakan manajer selain manajemen laba akrual dalam memanfaatkan kesempatan insentif perpajakan. Manajemen laba riil dapat dilakukan dengan pemanfaatan insentif yang diberikan otoritas perpajakan supaya perusahaan dalam bertahan dalam kondisi pandemi. Namun, adanya motif untuk mendapatkan keuntungan lebih besar dari perencanaan pajak melalui manajemen laba riil yang dilakukan oleh manajer. Dengan demikian, hipotesis kelima dalam penelitian ini sebagai berikut:

$\mathrm{H}_{5}$ : Manajemen laba riil memiliki pengaruh positif terhadap penghindaran pajak

\section{METODE DAN DATA}

Penelitian ini menggunakan pendekatan kuantitatif dengan menggunakan data sekunder yang diperoleh dari laporan keuangan Tahun 2019 sampai dengan Tahun 2020 perusahaan consumers good industry yang terdaftar di Bursa Efek Indonesia. Data laporan keuangan tersebut bersumber dari www.idx.co.id dan laman resmi perusahaan. Adapun ringkasan kriteria sampel berdasarkan purposive sampling adalah sebagai berikut:

Tabel 1. Sampel Penelitian

\begin{tabular}{lc}
\multicolumn{1}{c}{ Kriteria } & Jumlah \\
\hline Perusahaan Consumer Good Industry yang Terdaftar di BEI Tahun 2021 & 65 \\
Perusahan Listing di BEI & $(2)$ \\
Perusahaan yang IPO setelah 1 Januari 2019 & $(13)$ \\
Perusahaan yang telah mengumumkan Laporan Keuangan Tahun & $(13)$ \\
2020 sebelum 7 Mei 2021 & $\mathbf{3 7}$
\end{tabular}


Observasi

Total observasi

Sumber: data diolah

Dalam penelitian ini terdapat 3 variabel utama yaitu penghindaran pajak, manajemen laba akrual, dan manajemen laba riil yang digunakan dalam uji hipotesis 1,2 , dan 3. Sementara itu, dalam uji hipotesis 4 dan 5, variabel dependen penelitian ini adalah penghindaran pajak, sedangkan variabel independennya adalah manajemen laba akrual dan manajemen laba riil. Hanlon \& Heitzman (2010) menyebutkan bahwa ada 12 cara dalam menghitung proksi Penghindaran Pajak dan dalam Penelitian ini akan menggunakan 2 diantaranya sebagai proksi. Proksi pertama adalah effective tax rate (ETR) proksi ini membandingkan jumlah beban Pajak tahun berjalan dengan jumlah pendapatan sebelum Pajak. Nilai ETR yang rendah dapat mengindikasikan adanya praktik penghindaran Pajak karena rendahnya nilai ETR dapat diartikan sebagai rendahnya jumlah beban pajak yang ditanggung pada periode tersebut. ETR digunakan sebagai sebagai proksi untuk mengukur penghindaran pajak mengikuti Suhaidar et al. (2021), Makhfudloh et al. (2018), dan Hidayati \& Diyanty (2018) yaitu:

$$
\mathrm{ETR}=\frac{\text { Beban Pajak Penghasilan }}{\text { Laba Sebelum Pajak }}
$$

Sementara itu proksi kedua penghindaran pajak adalah cash effective tax rate (Cash ETR) yang menggambarkan rasio pajak yang dibayar oleh perusahaan per rupiah penghasilan yang diterima (Cheng et al. 2012). Nilai Cash ETR yang rendah dapat mengindikasikan adanya praktik penghindaran pajak. Proksi Cash ETR mengikuti Handayani et al. (2016), Firmansyah \& Muliana (2018), dan Ferdiawan \& Firmansyah (2017) dengan formula sebagai berikut:

$$
\text { Cash ETR }=\frac{\text { Pajak Penghasilan Yang dibayar }}{\text { Laba Sebelum Pajak }}
$$

Manajemen laba akrual dalam penelitian ini menggunakan akrual diskresioner dengan menggunakan model Kothari et al. (2005) atau performance matched discretionary accrual. Proksi ini juga digunakan oleh Firmansyah \& Irawan (2018), Talab et al. (2018), dan Bouchareb et al. (2014). Nilai akrual diskresioner didapatkan dengan menggunakan persamaan:

$$
\frac{\text { Accruals }}{\mathrm{TAt}-1}=\beta 0\left(\frac{1}{\mathrm{TAt}-1}\right)+\beta 1 \frac{\Delta \mathrm{REV}-\Delta \mathrm{REC}}{\mathrm{TAt}-1}+\beta 2 \frac{\mathrm{PPE}}{\mathrm{TAt}-1}+\beta 3 \mathrm{ROA}+\varepsilon
$$

\section{Keterangan}

Accruals : income after tax - cash from operation

TA t-1 : total aset perusahaan tahun sebelumnya

$\triangle \mathrm{REV} \quad$ : perubahan pendapatan dari periode sebelumnya

$\triangle$ REC : perubahan piutang dari periode sebelumnya

PPE : : plant, property, dan equipment

ROA $\quad$ : return on asset didapat dari net income dibagi total asset

$\varepsilon \quad$ : residual regresi yang merupakan estimasi akrual diskresioner

Manajemen laba riil dalam penelitian ini mengikuti Zang (2012) yaitu penjumlahan dari abnormal overproduction dan abnormal discretionary expense. Penelitian ini menggunakan model estimasi untuk biaya produksi normal Roychowdhury (2006). Adapun formula untuk mendapatkan nilai abnormal overproduction dengan menggunakan persamaan sebagai berikut:

$$
\frac{\mathrm{PROD}}{\mathrm{At}-1}=\alpha 0+\left(\frac{1}{\mathrm{At}-1}\right)+\beta 1\left(\frac{\mathrm{St}}{\mathrm{At}-1}\right)+\beta 2\left(\frac{\Delta \mathrm{St}}{\mathrm{At}-1}\right)+\beta 3\left(\frac{\Delta \mathrm{St}-1}{\mathrm{At}-1}\right)+\varepsilon
$$


Keterangan:

PROD/At- : biaya produksi pada tahun $\mathrm{t}$ yang diskala dengan total aktiva pada tahun $\mathrm{t}-1$, $1 \quad$ dimana PRODt $=$ COGSt $+\Delta \mathrm{INVt}$.

1/At-1 : intersep yang diskala dengan total aktiva pada tahun $\mathrm{t}-1$ dengan tujuan supaya arus kas kegiatan operasi tidak memiliki nilai 0 ketika penjualan dan lag penjualan bernilai 0

St/At-1 : penjualan pada tahun t yang diskala dengan total aktiva pada tahun t-1.

$\Delta$ St/At-1 : penjualan pada tahun $\mathrm{t}$ dikurangi penjualan pada tahun $\mathrm{t}-1$ yang diskala dengan total aktiva pada tahun $\mathrm{t}-1$

$\Delta$ St-1/At- $\quad$ : Perubahan penjualan pada tahun $\mathrm{t}-1$ yang diskala dengan total aktiva pada $1 \quad$ tahun $\mathrm{t}-1$

$\alpha 0 \quad:$ Konstanta

$\varepsilon \quad:$ residual pada tahun $\mathrm{t}$

Apabila hasil residual bernilai positif mengindikasikan bahwa perusahaan melakukan tindakan manajemen laba riil melalui manipulasi biaya produksi. Selanjutnya, manipulasi laba dengan cara menurunkan beban diskresioner dihitung dengan menggunakan model Roychowdhury (2006) sebagai berikut :

$$
\frac{D I S E X P i}{A t-1}=\alpha 0+\alpha 1\left(\frac{1}{A t-1}\right)+\beta 1\left(\frac{S t}{A t-1}\right) i+\varepsilon
$$

Keterangan:

DISEXP/At-1 : beban diskresioner didefinisikan sebagai jumlah dari beban iklan, beban riset dan pengembangan (research and development), beban penjualan, dan beban administrasi \& umum t yang diskala dengan total aktiva pada tahun $\mathrm{t}-1$

1/At-1 : intersep yang diskala dengan total aktiva pada tahun $\mathrm{t}-1$ dengan tujuan supaya arus kas kegiatan operasi tidak memiliki nilai 0 ketika penjualan dan lag penjualan bernilai 0

St/At-1 : penjualan pada tahun t yang diskala dengan total aktiva pada tahun $\mathrm{t}-1$.

$\alpha 0 \quad$ : Konstanta

$\varepsilon \quad:$ error term/residual pada tahun $\mathrm{t}$

Jika hasil residual bernilai negatif, mengindikasikan bahwa perusahaan melakukan tindakan manajemen laba riil melalui manipulasi discretionary expense, maka nilai residual dikalikan dengan -1. Penelitian ini juga menggunakan variabel kontrol yang terdiri dari profitabilitas, leverage, ukuran perusahaan, dan arus kas operasi. Dalam penelitian ini profitabilitas diukur menggunakan proksi Return On Equity (ROE) yaitu membandingkan laba setelah pajak dengan jumlah ekuitas perusahaan. Proksi ini mengikuti Silaban \& Siagian (2020), Utomo et al. (2016), dan Salim (2015) dengan formula sebagai berikut:

$$
R O E=\frac{\text { Net Income }}{\text { Equity }}
$$

Dalam penelitian ini nilai leverage diukur menggunakan debt to equity ratio (DER) sebagaimana Cahyono et al. (2016), Utomo et al. (2016), dan Salim (2015) dengan formula sebagai berikut:

$$
D E R=\frac{\text { Total Liability }}{\text { Equity }}
$$


Penelitian ini menggunakan logaritma natural asset untuk mengukur ukuran perusahaan sebagaimana Nugroho \& Firmansyah (2017), Alviyani (2016), dan Prasetia et al. (2014). Variabel arus kas operasi, dalam penelitian sebelumnya diukur dengan arus kas operasi dengan total asset seperti Dewi \& Maifoza (2018), Jayanti \& Sapari (2016), dan Purwanti (2014), namun dalam penelitian ini dilakukan penyesuaian dengan membagi arus kas operasi dengan rata-rata aset tahun berjalan dan aset tahun sebelumnya sebagaimana formula sebagai berikut:

$$
\text { OCF }=\frac{\text { Cash From Operation }}{\left(\frac{\text { Aset } t+\text { Aset } t-1}{2}\right)}
$$

Pengujian hipotesis 1, 2, dan 3 dalam penelitian dilakukan dengan menggunakan uji beda. Sementara itu, untuk pengujian hipotesis 4 dan 5 dilakukan dengan menggunakan analisis regresi linier berganda untuk data cross sectional. Untuk menguji Hipotesis 4 dan 5 digunakan 2 model penelitian sebagai berikut:

Model 1

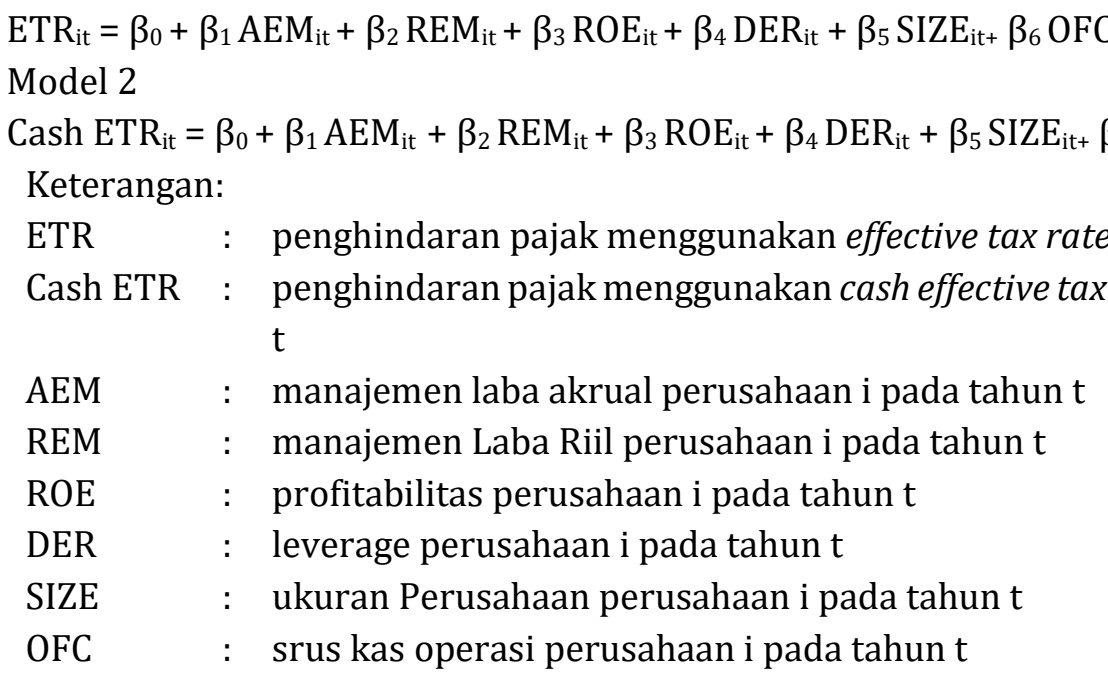

\section{PEMBAHASAN}

Tabel 2 menunjukkan statistik deskriptif untuk setiap variabel pada periode sebelum Pandemi.

Tabel 2. Statistik Deskriptif Variabel Era Sebelum Pandemi

\begin{tabular}{ccccccc}
\hline Variabel & Mean & Median & Max & Min & Std. Dev. & Obs \\
\hline ETR 2019 & 0,237236 & 0,248524 & 0,585280 & $-0,736976$ & 0,189767 & 37 \\
C ETR & 0,436659 & 0,219946 & 5,725730 & $-0,329189$ & 1,014333 & 37 \\
2019 & & & & \\
AEM 2019 & $-9.00 \times 10^{-18}$ & -0.026302 & 0.468247 & -0.194329 & 0.116195 & 37 \\
REM 2019 & $5.24 \times 10^{-16}$ & 0.014221 & 0.741335 & -0.793909 & 0.330202 & 37 \\
CFO 2019 & 0 & -0.008131 & 0.270168 & -0.308387 & 0.114921 & 37 \\
PROD & & & & & & \\
2019 & $4.47 \times 10^{-16}$ & 0.000809 & 0.427618 & -0.496498 & 0.191272 & 37 \\
DISEX & & & & & & \\
2019 & $4.05 \times 10^{-17}$ & 0.035283 & 0.313717 & -0.361159 & 0.161759 & 37 \\
ROE 2019 & 0,149308 & 0,123260 & 1,399665 & $-0,684485$ & 0,317238 & 37 \\
DER 2019 & 0,751159 & 0,544200 & 2,909487 & $-2,127341$ & 0,812703 & 37 \\
SIZE 2019 & 28.924590 & 28.470340 & 32.725608 & 25.779658 & 1.695034 & 37
\end{tabular}




\begin{tabular}{ccccccc} 
OCF 2019 & 0,111486 & 0,105728 & 0,461258 & $-0,194849$ & 0,143502 & 37 \\
\hline \multicolumn{6}{c}{ Sumber: data diolah }
\end{tabular}

Tabel 3 menunjukkan statistik deskriptif untuk setiap variabel pada era Pandemi.

Tabel 3. Statistik Deskriptif Variabel Era Pandemi

\begin{tabular}{ccccccc}
\hline Variabel & Mean & Median & Max & Min & Std. Dev. & Obs. \\
\hline ETR 2020 & 0,258322 & 0,224778 & 1,008319 & $-0,194929$ & 0,262399 & 37 \\
C ETR & 0,190693 & 0,169162 & 0,885453 & $-0,377420$ & 0,236101 & 37 \\
2020 & & & & & & \\
AEM 2020 & $5.25 \times 10^{-18}$ & -0.028766 & 0.582984 & -0.131569 & 0.115375 & 37 \\
REM 2020 & $-1.34 \times 10^{-16}$ & 0.032473 & 0.735582 & -0.988752 & 0.348796 & 37 \\
CFO 2020 & $-2.18 \times 10^{-17}$ & 0.015697 & 0.149781 & -0.174628 & 0.080169 & 37 \\
PROD & $-1.20 \times 10^{-16}$ & 0.024491 & 0.498764 & -0.539228 & 0.175688 & 37 \\
2020 & & & & & & \\
DISEX & $0.53 \times 10^{-17}$ & 0.047702 & 0.248586 & -0.924277 & 0.216370 & 37 \\
2020 & & & & & \\
ROE 2020 & 0,146417 & 0,117356 & 1,454829 & $-0,467160$ & 0,351201 & 37 \\
DER 2020 & 0,893157 & 0,754652 & 3,159024 & 0,079410 & 0,736132 & 37 \\
SIZE 2020 & 28.842540 & 28.567582 & 32.197435 & 25.752520 & 1.636945 & 37 \\
OCF 2020 & 0,116342 & 0,112454 & 0,406177 & $-0,030143$ & 0,098159 & 37 \\
\hline \multicolumn{7}{c}{ Sumber: data diolah } \\
\end{tabular}

Tabel 4 menunjukkan statistik deskriptif untuk setiap variabel pada era Sebelum Pandemi dan Saat Pandemi.

Tabel 4. Statistik Deskriptif Variabel Era Sebelum dan Saat Pandemi

\begin{tabular}{ccccccc}
\hline Variabel & Mean & Median & Max & Min & Std. Dev. & Obs \\
\hline ETR & 0,247779 & 0,242205 & 1,008319 & $-0,736976$ & 0,227655 & 74 \\
C ETR & 0,313676 & 0,205507 & 5,725730 & $-0,377420$ & 0,741762 & 74 \\
AEM & $-1.88 \times 10^{-18}$ & -0.026864 & 0.582984 & -0.194329 & 0.114990 & 74 \\
REM & $1.97 \times 10^{-16}$ & 0.026317 & 0.741335 & -0.988752 & 0.337292 & 74 \\
CFO & $-1.09 \times 10^{-17}$ & 0.000195 & 0.270168 & -0.308387 & 0.098400 & 74 \\
PROD & $1.80 \times 10^{-16}$ & 0.012650 & 0.498764 & -0.539228 & 0.182383 & 74 \\
DISEX & $2.06 \times 10^{-17}$ & 0.038070 & 0.313717 & -0.924277 & 0.189713 & 74 \\
ROE & 0,147862 & 0,119606 & 1,454829 & $-0,684485$ & 0,332354 & 74 \\
DER & 0,822158 & 0,654441 & 3,159024 & $-2,127341$ & 0,773345 & 74 \\
SIZE & 28.883565 & 28.518961 & 32.725608 & 25.752520 & 1.655306 & 74 \\
OCF & 0,113914 & 0,108207 & 0,461258 & $-0,194849$ & 0,122119 & 74 \\
\hline
\end{tabular}

Sumber: data diolah

Ringkasan uji Komparatif yang menguji hipotesis 1, 2 dan 3 terdapat dalam Tabel 5 dan 6 sebagai berikut:

Tabel 5. Ringkasan Uji Komparatif "Ranks"

\begin{tabular}{cccccccccc}
\hline \multirow{2}{*}{ Var. } & \multicolumn{3}{c}{ Negative Ranks } & \multicolumn{3}{c}{ Positive Rank } & Ties & Total \\
\cline { 2 - 8 } & Q & Mean & Sum & Q & Mean & Sum & Q & Q \\
\hline ETR & 25 & 18.40 & 460.00 & 12 & 20.25 & 243.00 & 0 & 37 \\
CETR & 21 & 20.52 & 430.92 & 15 & 15.67 & 235.05 & 1 & 37 \\
AEM & 20 & 17.15 & 343.00 & 17 & 21.18 & 360.0 & 0 & 37
\end{tabular}




\begin{tabular}{ccccccccc} 
REM & 15 & 17.67 & 265.00 & 22 & 19.91 & 438.0 & 0 & 37 \\
PROD & 20 & 18.75 & 375.00 & 17 & 19.29 & 328.00 & 0 & 37 \\
DISEX & 11 & 13.64 & 150.00 & 26 & 21.27 & 553.00 & 0 & 37 \\
\hline
\end{tabular}

Tabel 6. Ringkasan Uji Komparatif

\begin{tabular}{|c|c|}
\hline Variabel & Uji Paired Sample t-Test \\
\hline PROD & 1.00 \\
\hline Variabel & Uji Wilcoxon Asymp. Sig. (2-tailed) \\
\hline ETR & 0.102 \\
\hline C ETR & 0.124 \\
\hline AEM & 0.898 \\
\hline REM & 0192 \\
\hline DISEX & 0.002 \\
\hline
\end{tabular}

Sumber: data diolah

Sementara, uji hipotesis 4 dan 5 , terdapat dapat Tabel 7 sebagai berikut:

Tabel 7. Ringkasan Uji Hipotesis 4 dan 5

\begin{tabular}{cccccccccc}
\hline & \multicolumn{3}{c}{ Model 1 (ETR) } & \multicolumn{4}{c}{ Model 2 (C ETR) } \\
\hline Var. & Coeff. & t-Stat. & Prob. & & Coeff. & t-Stat. & Prob. \\
\hline C & 1.688 & 2.408 & 0.022 & $* *$ & 0.557 & 0.805 & 0.427 & \\
AEM & -0588 & -0.960 & 0.345 & & -0.298 & -0.494 & 0.625 & \\
REM & 0.243 & 2.027 & 0.052 & $*$ & 0.130 & 1.099 & 0.280 & \\
DER & 0.143 & 2.362 & 0.025 & $* *$ & -0.119 & -1.992 & 0.055 & $*$ \\
OCF & -0.273 & -0.471 & 0.641 & & -0.946 & -1.649 & 0.109 & \\
ROE & 0.025 & 0.136 & 0.893 & & 0.347 & 1.920 & 0.064 & $*$ \\
SIZE & -0.051 & -2.036 & 0.051 & $*$ & -0.006 & -0.251 & 0.804 & \\
R $^{2}$ & & 0.373 & & & & 0.245 & \\
Adj. R & & 0.246 & & & & 0.094 & \\
F-stat. & & 2.970 & & & & 1.620 & & \\
Prob(F-stat.) & & 0.021 & & & 0.176 & &
\end{tabular}

Sumber: data diolah

Dari Tabel 7, terlihat bahwa nilai Prob F-stat dari Model 2 yang menggunakan Cash ETR sebagai proksi penghindaran pajak adalah sebesar 0.176, dimana hasil ini lebih besar dari 0,05 dan sesusai dengan uji $\mathrm{F}$ maka model 2 dinyatakan tidak layak untuk memprediksi variabel dependen, sedangkan untuk model 1 yang menggunakan ETR sebagai Proksi penghindaran Pajak dinyatakan layak untuk memprediksi variabel dependen karena memiliki nilai Prob F-stat lebih kecil dari 0.05 dan selanjutnya akan digunakan sebagai dasar pembahasan dalam penelitian ini.

\section{Perbedaan tingkat manajemen laba akrual sebelum dan setelah masa pandemi}

Hasil pengujian hipotesis menunjukkan bahwa tidak terdapat perbedaan tingkat manajemen laba akrual sebelum dan setelah masa pandemi. Hasil ini berbeda dengan penelitian yang dilakukan oleh Azizah (2021). Hasil yang berbeda ini dapat terjadi karena adanya perbedaan jumlah sampel, sektor, periode, dan proksi yang dipilih dalam menentukan tingkat manajemen laba akrual. Pengujian yang dilakukan oleh Azizah (2021) menggunakan 62 perusahaan manufaktur dan menggunakan proksi manajemen laba akrual dengan model Dechow et al. (1995) pada periode Q1 Tahun 2019 dan Q1 Tahun 2020. Sementara itu, penelitian ini menggunakan data 37 Perusahaan sektor barang konsumsi dan menggunakan proksi manajemen akrual dengan model 
Kothari et al. (2005) serta perhitungan menghitung manajemen laba akrual untuk data perusahaan dalam satu tahun pada periode untuk tahun 2019 dan tahun 2020.

Dari analisa deskriptif pada penelitian ini ditemukan bahwa perusahaan sampel tetap melakukan kegiatan manajemen laba akrual pada masa pandemi, tetapi secara rata-rata aktivitas manajemen laba menjadi turun dibandingkan dengan periode sebelum pandemi. Dari sudut pandang pemegang saham, tindakan manajemen laba yang dilakukan oleh manajer dianggap sebagai tindakan yang wajar dalam kondisi perlambatan ekonomi secara nasional bahkan internasional yang diakibatkan oleh pandemi Covid-19 (Azizah, 2021). Kondisi pandemi bukan dijadikan kesempatan bagi manajer untuk melakukan manajemen laba akrual yang dipengaruhi oleh motif-motif pribadi. Tindakan manajemen laba dapat juga dipengaruhi oleh tujuan spesifik lainnya yang ingin diperoleh dari laba yang dilaporkan (Scott, 2015). Tujuan-tujuan ini dapat berupa penghindaran pajak. Manajer diduga lebih memikirkan keberlangsungan perusahaan di masa depan dibandingkan hanya menggunakan diskresinya untuk melakukan manajemen laba yang menguntungkan pribadinya. Dalam kondisi pandemic, manajer tetap mempertimbangkan kondisi perusahaan sebagai dasar penentuan tingkat manajemen laba yang dilakuan. Sebagai contoh perusahaan BUMN Farmasi yang mendapat tugas pengadaan vaksin yaitu PT KAEF dari analisis deskriptif dilaporkan bahwa perusahaan ini menurunkan tingkat manajemen laba akrual pada periode pandemi dan tetap dapat mencatatkan kenaikan laba. Disisi lain, perusahaan farmasi PT KLBF yang pada periode Tahun 2020 belum mendapat tugas pengadaan vaksin juga mencatatkan kenaikan laba namun bersamaan dengan kenaikan tingkat manajemen laba akrual.

\section{Perbedaan tingkat Manajemen Laba Riil sebelum dan setelah masa pandemi}

Dari hasil pengujian hipotesis menunjukkan bahwa tidak terdapat perbedaan tingkat manajemen laba riil sebelum dan setelah masa pandemi. Pada penelitian ini, nilai REM merupakan penjumlahan dari nilai manipulasi produksi dan manipulasi beban diskresioner sesuai dengan model Zang (2012), sehingga akan lebih mudah dijelaskan jika kita melihat dari dua manipulasi ini. Pertama dari sisi manipulasi produksi, manajemen dapat meningkatkan laba perusahaan dengan cara mengurangi COGS melalui kegiatan overproduction. Namun manipulasi ini tentu memiliki konsekuensi penambahan $b$, seperti biaya penyimpanan dan penanganan. Oleh karena itu, opsi manipulasi ini dipandang kurang menarik bagi manajemen sehingga sesuai dengan hasil uji beda lebih banyak perusahaan yang melakukan penurunan tingkat manipulasi produksi. Kondisi ini dapat terjadi karena manajemen dalam memilih metode manajemen laba akan dipengaruhi oleh biaya dari metode tersebut (Zang, 2012).

Selanjutnya, dari sisi manipulasi beban diskresioner, hasil pengujian menunjukkan bahwa pandemi menaikkan tingkat manipulasi beban diskresioner. Kondisi pandemi mengakibatkan kegiatan ekonomi perusahaan menjadi tidak pasti. Perusahaan-perusahaan berusaha menekan beban-beban diskresioner. Selain itu, peraturan Pembatasan Sosial Berskala Besar (PSBB) sesuai amanat Peraturan Pemerintah nomor 21 Tahun 2020 yang dimulai sejak Bulan April 2020 kemungkinan juga mempengaruhi perusahaan untuk menunda pelaksanaan peningkatan kompetensi pegawainya yang membuat beban diskresioner berupa beban pelatihan pegawai menjadi turun.

Dalam kondisi pandemi, selain di sisi investor dan shareholder yang memaklumi jika kinerja operasi perusahaan pada periode pandemi tidak sesuai yang diharapkan, laba yang terlalu tinggi akan dipandang "too good to be true" sehingga hanya akan menimbulkan kecurigaan bagi publik, auditor, bahkan shareholders. Oleh karena itu, manajemen laba agresif yang dilakukan oleh manajer pada periode pandemi malah dapat mengancam kedudukan manajemen tersebut (Azizah, 2021). Walaupun pada hasil uji beda terdapat lebih banyak perusahaan yang melakukan peningkatan manajemen laba riil, kondisi ini lebih diakibatkan oleh banyaknya perusahaan yang melakukan penekanan beban diskresioner, dimana penekanan beban ini dianggap dapat diterima atau bahkan dianggap wajar oleh pemegang saham mengingat terjadinya kondisi pandemi yang berasal dari faktor eksternal perusahaan.

\section{Perbedaan Tingkat Penghindaran Pajak Sebelum Dan Setelah Masa Pandemic}


Hasil pengujian hipotesis menunjukkan bahwa tidak terdapat perbedaan tingkat penghindaran pajak sebelum dan setelah masa pandemi. Walaupun pada saat pandemi terdapat kesempatan bagi manajer untuk memanfaatkan penghindaran pajak lebih besar seperti adanya insentif perpajakan, kondisi tersebut tidak mengakibatkan manajer lebih agresif dalam melakukan penghindaran pajak. Hasil pengujian ini tidak sejalan dengan Suhaidar et al. (2021). Meskipun perusahaan menganggap pajak sebagai beban, dalam porsi yang signifikan akan mengurangi sebagian dari laba yang telah diperoleh perusahaan (Pipatnarapong et al., 2020), sehingga pemilik perusahaan akan mendorong manajemen untuk mengurangi beban pajak yang timbul dengan melaksanakan agresivitas pajak (Chen et al., 2010). Walaupun pandemi memaksa diadakannya work from home bagi para Pegawai Direktorat Jenderal Pajak tidak mengurangi tingkat pengendalian dan pengawasan terhadap pemberian insentif perpajakan. Disisi lain dalam kondisi pandemi, insentif perpajakan berupa penurunan tarif Pph dapat membuat manajemen perusahaan memfokuskan pada tujuan lain selain penghindaran pajak, seperti mencapai target laba yang ditentukan karena pada masa pandemi menjadi tantangan tersendiri terkait dengan melambatnya perekonomian. Hasil analisis deskriptif menunjukkan pada periode pandemi walaupun pemerintah telah memberikan insentif perpajakan ditemukan kenaikan nilai rata-rata rasio beban pajak terhadap pendapatan sebelum pajak, yaitu menjadi $25,83 \%$, sedangkan periode sebelumnya hanya sebesar $23,72 \%$. Untuk nilai median ditemukan adanya penurunan dimana pada periode sebelum pandemi nilai median sebesar $24,85 \%$ turun menjadi $22,47 \%$, namun penurunan ini tidak dapat dikategorikan sebagai peningkatan penghindaran pajak karena Selama masa Pandemi melalui Perppu Nomor 1 Tahun 2020, Pemerintah Indonesia memberikan penyesuaian tarif Pajak untuk tahun 2020 menjadi sebesar 22\%, Selain itu Perusahaan yang sudah Go Public dan telah memenuhi persyaratan pada Pasal 5 ayat 3 Perppu Nomor 1 Tahun 2020, berhak mendapatkan tarif PPh sebesar 19\%.

\section{Pengaruh Manajemen Laba Akrual terhadap Penghindaran Pajak}

Hasil pengujian hipotesis menunjukkan bahwa selama periode pandemi tindakan manajemen laba akrual perusahaan tidak berpengaruh terhadap penghindaran pajak. Hasil pengujian ini tidak sejalan dengan Pajriyansyah \& Firmansyah (2017), Tiaras \& Wijaya (2015), dan Suyanto \& Supramono (2012). Meskipun manajemen laba untuk tujuan fiskal dan komersial dapat dilakukan bersamaan (Frank, et al, 2004), sehingga perusahaan dapat menaikkan laba bersih dengan diikuti turunnya penghasilan kena pajak perusahaan (Nugroho \& Firmansyah, 2017). Oleh karena itu, perusahaan yang melakukan manajemen laba akan meningkatkan kemungkinan perusahaan untuk melakukan kegiatan tax shelter (Geraldina, 2013). Akan tetapi, manajemen laba akrual pada sektor consumers good industry dilakukan bukan untuk tujuan penghindaran pajak, tetapi digunakan untuk tujuan lainnya diduga untuk memperoleh bonus dan mendapatkan tambahan utang (Saksessia \& Firmansyah, 2020).

Adapun kondisi pandemi saat ini memberikan dampak negatif terhadap kinerja perusahaan, terutama untuk perusahaan consumers goods industry. Penurunan konsumsi mengakibatkan perusahaan juga mengalami masalah terkait penjualan, sehingga manajer dapat meningkatkan penyisihan piutang tak tertagih. Akibatnya, laba menjadi semakin kecil dan menurunkan corporate tax turun. Maka dapat disimpulkan bahwa kesempatan akibat pandemi tidak menyebabkan manajer untuk meningkatkan laba akrual karena motivasi dari manajer hanya untuk memberikan full-disclosure.

Pada era pandemi penghindaran pajak mungkin sudah tidak menjadi tujuan utama dari manajemen laba disebabkan penurunan tarif perpajakan. Oleh karena itu, manajer dapat menggunakan manajemen laba untuk tujuan lain seperti mengejar insentif berupa bonus melalui income smoothing (Scott, 2015). Namun, penggunaan manajemen laba untuk tujuan insentif ini tetap dilakukan secara terukur serta menggunakan manipulasi yang dapat dianggap wajar seperti manipulasi beban diskresioner pada manajemen laba riil. Hal ini dilakukan demi menghindari kecurigaan dari para pemegang saham atau auditor yang dapat membahayakan jabatannya (Azizah, 2021). Di sisi lain, pada perusahaan terbuka manajemen laba yang digunakan untuk tujuan penghindaran pajak seringkali terbentur dengan tekanan dari pemegang saham untuk dapat meningkatkan laba (Rahmadani et al., 2020). 


\section{Pengaruh Manajemen Laba Riil terhadap Penghindaran Pajak}

Hasil pengujian hipotesis menunjukkan bahwa pada periode pandemi manajemen laba riil berpengaruh positif terhadap ETR. Hasil tersebut menunjukkan bahwa pada periode pandemi tingkat penghindaran pajak menjadi turun ketika manajer dalam perusahaan menggunakan manipulasi laba melalui aktivitas riil. Hasil penelitian ini sejalan dengan Machdar (2019), namun tidak sejalan dengan Surahman \& Firmansyah (2017), Ferdiawan \& Firmansyah (2017), Handrian (2018), dan Putra (2018). Periode pandemi mengakibatkan tingginya ketidakpastian kondisi perekonomian mengakibatkan penggunaan manajamen laba riil oleh manajer diduga tidak ditujukan untuk aktivitas penghindaran pajak. Manajemen laba riil dilakukan oleh manajer untuk meningkatkan laba perusahaan demi mencapai target laba yang sudah ditentukan. Meskipun pandemi cenderung tidak mengganggu perusahaan di sektor consumers goods industry sebesar perusahaan sektor lain, namun peningkatan laba perlu dilakukan perusahaan untuk meyakinkan pemilik perusahaan terkait dengan keberlangsungan perusahaan di masa depan. Usaha manajer untuk mencapai laba yang sudah ditargetkan ini dapat didasari demi meraih kepercayaan pemegang saham dengan harapan tetap diberi kesempatan untuk menduduki jabatan yang dijalankan saat ini. Oleh karena itu, manajer melakukan seluruh upaya agar dapat memenuhi laba yang di targetkan salah satunya dengan strategi melakukan praktik manajemen laba riil. Akan tetapi, dengan adanya insentif dari pemerintah berupa penurunan tarif pajak, membuat biaya relatif penggunaan praktik manajemen laba riil menjadi lebih rendah sehingga manajer lebih leluasa dalam melakukan praktik manajemen laba riil. Di sisi lain, kelebihan manajemen laba riil berupa lebih sulit dideteksi oleh pegawai Otoritas Pajak membuat perusahaan tidak menggunakan diskresinya dalam melakukan manajemen laba untuk motif penghindaran pajak yang rentan dengan pemeriksaan pajak di masa mendatang dan berisiko membahayakan jabatannya.

Adanya pandemi mengakibatkan manajer menggunakan manajemen laba riil untuk tindakan efisiensi (Scott, 2015; Siregar \& Utama, 2008) dengan tujuan untuk mendapatkan kepercayaan pemegang saham dan keberlangsungan perusahaan di masa mendatang. Faktor eksternal perusahaan yang dapat mengakibatkan risiko kebangkrutan perusahaan cenderung utk menurunkan informasi asimeteri antara manajer dan pemegang saham. Oleh karena itu, dalam kondisi ini masalah keagenan sebagaimana dalam teori keagenan dapat diminimalisir.

\section{SIMPULAN}

Berdasarkan hasil pengujian yang telah dilakukan, penelitian ini menyimpulkan bahwa tidak terdapat perbedaan tingkat manajemen laba akrual sebelum dan setelah masa pandemi. Manajer tidak memanfaatkan kondisi pandemi untuk mengubah tingkat manajemen laba akrual. Manajemen perusahaan tetap mempertimbangan kondisi internal perusahaan sebagai dasar penentuan tingkat manajemen laba yang digunakan. Sementara itu, secara umum tidak terdapat perbedaan tingkat manajemen laba riil sebelum dan setelah masa pandemi. Manajer tidak menggunakan diskresinya untuk meningkatkan biaya produksi, namun terdapat indikasi adanya penurunan beban diskresioner dalam masa pandemi untuk mempertahankan sejumlah laba tertentu. Selain itu, tidak terdapat perbedaan tingkat Penghindaran Pajak sebelum dan setelah masa pandemi. Secara umum memang terdapat penurunan rata-rata ETR pada periode pandemi, namun kondisi tersebut tidak menunjukkan adanya kenaikan penghindaran pajak pada masa pandemi secara signifikan, namun lebih dipengaruhi karena adanya pemberian insentif penurunan tarif PPh oleh Pemerintah. Selanjutnya, manajemen laba akrual tidak dilakukan untuk tujuan penghindaran pajak, sedangkan tindakan manajemen laba riil malah menurunkan aktivitas penghindaran pajak. Manajer perusahaan memanfaatkan manajemen laba cenderung untuk meningkatkan efisiensi dan mempertahankan kinerja perusahaan dalam kondisi yang tidak pasti akibat faktor eksternal.

Penelitian ini memiliki keterbatasan yaitu sampel yang digunakan dalam penelitian ini 
hanya menguji perusahaan sektor consumer goods industry, sehingga tidak dapat menggambarkan kondisi seluruh perusahaan di Indonesia. Selain itu, rentang waktu dalam penelitian ini terlalu pendek yaitu dari tahun 2019 dan 2020 yang mengakibatkan jumlah sampel yang relatif kecil. Penelitian Selanjutnya dapat menggunakan rentang waktu penelitian yang lebih panjang dan sampel yang lebih banyak agar mendapatkan hasil yang lebih komprehensif. Untuk mengatasi adanya perbedaan tarif $\mathrm{PPh}$ antara periode sebelum pandemi dan saat pandemi, penelitian selanjutnya dapat menggunakan Book Tax Difference (BTD) sebagai proksi penghindaran pajak.

Penelitian ini mengindikasikan bahwa Otoritas Perpajakan di Indonesia perlu memperhatikan kemungkinan tindakan penghindaran pajak yang dilakukan oleh perusahaan selaku wajib pajak selama masa pandemi termasuk dengan menggunakan teknik manajemen laba. Selain itu, dalam menghadapi kondisi-kondisi yang tidak mendukung secara eksternal seperti adanya pandemi, Otoritas Perpajakan di Indonesia perlu untuk meningkatkan prosedur monitoring dan pengendalian terkait dengan aktivitas penghindaran pajak yang dilakukan oleh perusahaan.

\section{DAFTAR PUSTAKA}

Alviyani, K. (2016). Pengaruh corporate governance, karakter eksekutif, ukuran perusahaan, dan leverage terhadap penghindaran pajak (tax avoidance). JOM Fekon, 3(1), 2540-2554.

Ardy, A., \& Kristanto, A. B. (2015). Faktor finansial dan non finansial yang mempengaruhi agresivitas pajak di indonesia. Media Riset Akuntansi, Auditing \& Informasi, 15(1), 31-48.

Arham, A., Firmansyah, A., Nor, A. M. E., \& Vito, B. (2020). a bibliographic study on tax avoidance research in Indonesia. International Journal of Psychosocial Rehabilitation, 24(7), 9526-9554

Asmara, C. G. (2020). Indonesia resmi resesi, ini buktinya "perihnya" di masyarakat. CNBCIndonesia.com. Diunduh dari https://www.cnbcindonesia.com/news/20201107082302-4-200008/indonesia-resmiresesi-ini-buktinya-perihnya-di-masyarakat

Azizah, W. (2021). Covid-19 in Indonesia: analysis of differences earnings management in the first quarter. Jurnal Akuntansi, 11(1), 23-32. https://doi.org/10.33369/j.akuntansi.11.1.23-32

Badertscher, B. A. (2011). Overvaluation and the Choice of Alternative Earnings Management Mechanisms. The Accounting Review, 86(5), 1491-1518. https://doi.org/10.2308/accr$\underline{10092}$

Bouchareb, M., Ajina, A., \& Souid, S. (2014). Does the adoption of IAS/IFRS with a strong governance mechanism can deter earnings management? International Journal of Academic Research in Economics and Management Sciences, 3(1), 264-282. https://doi.org/10.6007/ijarems/v3-i1/645

Cahyono, D., Andini, R., \& Raharjo, K. (2016). Pengaruh komite audit, kepemilikan institusional, dewan komisaris, ukuran perusahaan (Size), leverage (DER) dan profitabilitas (ROA) terhadap tindakan penghindaran pajak (tax avoidance) pada perusahaan perbankan yang listing BEI Periode Tahun 2011 - 2013. Journal Of Accounting, 2(2), 1-10.

Chen, S., Chen, X., Cheng, Q., \& Shevlin, T. (2010). Are family firms more tax aggressive than nonfamily firms? Journal of Financial Economics, 95(1), 41-61. https://doi.org/10.1016/j.jfineco.2009.02.003

Cohen, D. A., Dey, A., \& Lys, T.Z. (2008). real and accrual-based earnings management in the preand post- sarbanes oxley period. The Accounting Review, 83(3), 757-787. 
Cohen, D. A., \& Zarowin, P. (2010). Accrual-based and real earnings management activities around seasoned equity offerings. Journal of Accounting and Economics, 50(1), 2-19.

Damayanti, H. H., \& Prastiwi, D. (2017). Peran OECD dalam meminimalisasi upaya tax agresiveness pada perusahaan multinationality. Jurnal Akuntansi Multiparadigma (JAMAL), $8(1), 1-227$.

Dechow, P., Sloan, R. \& Sweeney, A. (1995). Detecting earnings management. The Accounting Review, 70, 193-225.

Desai, M. A., \& Dharmapala, D. (2009). Earnings management, corporate tax shelters, and booktax alignment. National Tax Journal, 62(1), 169-186. https://doi.org/10.17310/ntj.2009.1.08..

Dewi, S. P., \& Cynthia, C. (2018). Aggressiveness tax in indonesia. Jurnal Akuntansi, 22(2), 239. https://doi.org/10.24912/ja.v22i2.350.

Eastman, E., Ehinger, A., \& Xu, J. (2020). Enterprise risk management and corporate tax avoidance. SSRN Electronic Journal. https://doi.org/10.2139/ssrn.3717865.

Fathimah Timorria, I. (2021). Apindo: Pemanfaatan Insentif Pajak Tetap Terbatas. Bisnis.com. Diunduh pada 1 Juni 2021, dari https://ekonomi.bisnis.com/read/20210204/12/1352175/apindo-pemanfaatan-insentifpajak-tetap-terbatas.

Ferdiawan, Y. \& Firmansyah A. (2017). Pengaruh political connection, dan real earnings management terhadap tax avoidance.

foreign activity, Keuangan, 5 (3), 2017, 1601-1624.

Firmansyah, A., \& Irawan, F. (2018). Adopsi IFRS, manajemen laba akrual dan manajemen laba riil. Assets: Jurnal Akuntansi Dan Pendidikan, 7(2), 81. https://doi.org/10.25273/jap.v7i2.3310

Frank, M. M., Lynch, L. J., \& Rego, S. O. (2004). Does aggressive financial reporting accompany aggressive tax reporting (and vice versa). Working Paper. Available in https://doi.org/10.2139/ssrn.647604

Geraldina, I. (2013). Preferensi Manajemen Laba Akrual Atau Manajemen Laba Riil Dalam Aktivitas Tax Shelter. Jurnal Akuntansi Dan Keuangan Indonesia, 10(2), 206-224. https://doi.org/10.21002/jaki.2013.11

Gunawan, J. (2017). Pengaruh corporate social responsibility dan corporate governance terhadap agresivitas pajak. Jurnal Akuntansi, 21(3), 425. https://doi.org/10.24912/ja.v21i3.246

Handayani, M., Harimurti, F., \& Kristianto, D. (2016). Standar ukuran perusahaan yang telah melakukan manajemen pajak dengan indikator cash ETR (studi empiris pada perusahaan food and beverage yang terdaftar di bursa efek indonesia periode 2013-2016). Jurnal Akuntansi Dan Sistem Teknologi Informasi, 15(2), 123-131.

Handrian, M. (2018). Pengaruh manajemen laba riil dan tata kelola terhadap penghindaran pajak pada perusahaan manufaktur yang terdaftar di bursa efek indonesia periode 2010-2016. Skripsi: Fakultas Ekonomi, Universitas Tarumanagara.

Hanlon, M., \& Heitzman, S. (2010). A review of tax research. Journal of Accounting and Economics, 50(2-3), 127-178. https://doi.org/10.1016/j.jacceco.2010.09.002.

Hanna, H., \& Haryanto, M. (2017). Agresivitas pelaporan keuangan, agresivitas pajak, tata kelola perusahaan dan kepemilikan keluarga. Jurnal Akuntansi, 20(3), 407-419. https://doi.org/10.24912/ja.v20i3.6.

Harnovinsah, \& Septyana. (2016). Dampak tax accounting choices terhadap tax aggressive. Jurnal 
49 | Bina Ekonomi

Akuntansi, 20(02), 267-284.

Hidayati, W., \& Diyanty, V. (2018). Pengaruh moderasi koneksi politik terhadap kepemilikan keluarga dan agresivitas pajak. Jurnal Akuntansi \& Auditing Indonesia, 22(1), 46-60. https://doi.org/10.20885/jaai.vol22.iss1.art5.

Huseynov, F., \& Klamm, B. K. (2012). Tax avoidance, tax management and corporate social responsibility. Journal of Corporate Finance, 18(4), 804-827. https://doi.org/10.1016/j.jcorpfin.2012.06.005.

Irawan, F., \& Turwanto, T. (2020). The effect of tax avoidance on firm value with tax risk as moderating variable. Test Engineering \& Management, 83, 9696 - 9707

Jayanti, A., \& Sapari. (2016). Pengaruh positive accounting theory, profitabilitas dan operating cash flow terhadap penerapan konservatisme. Jurnal Ilmu Dan Riset Manajemen, 5(10), 1-17.

Jensen, M. C., \& Meckling, W. H. (1976). Theory of the firm: managerial behavior, agency costs and ownership structure. Journal of Financial Economics 3 (1976) 305-360.

Kementerian Keuangan RI. (2020). Pemerintah Berikan Insentif Pajak untuk Dukung Dunia Usaha dan Masyarakat Selama Pandemi COVID-19. Kementerian Keuangan. Diunduh 1 Juni 2021, dari https://www.kemenkeu.go.id/publikasi/berita/pemerintah-berikan-insentifpajak-untuk-dukung-dunia-usaha-dan-masyarakat-selama-pandemi-covid-19/.

Kothari, S. P., Leone, A. J., \& Wasley, C. E. (2005). Performance matched discretionary accrual measures. Journal of Accounting and Economics, 39(2005), 163-197.

Kusuma, H. (2020). 5 Sektor Usaha yang Paling Banyak Nikmati Insentif Pajak. detikfinance. Diunduh 1 Juni 2021, dari https://finance.detik.com/berita-ekonomi-bisnis/d-5070074/5.

Makhfudloh, F., Herawati, N., \& Wulandari, A. (2018). Pengaruh corporate social responsibility terhadap perencanaan agresivitas pajak.

Jurnal Akuntansi Dan Bisnis,

18(1), 48. https://doi.org/10.20961/jab.v18i1.235.

Maraya, A. D., \& Yendrawati, R. (2016). Pengaruh corporate governance dan corporate social responsibility disclosure terhadap tax avoidance: studi empiris pada perusahaan tambang dan CPO. Jurnal Akuntansi \& Auditing Indonesia, 20(2), 147-159. https://doi.org/10.20885/jaai.vol20.iss2.art7.

Machdar, N. M. (2019). Agresivitas pajak dari sudut pandang manajemen laba. Jurnal Riset Manajemen Dan Bisnis (JRMB) Fakultas Ekonomi UNIAT, 4(1), 183-192.

Nordiansyah, E. (2020). Lebih dari 451 Ribu Pengusaha Minta Insentif Pajak, Berapa yang Disetujui?. medcom.id. Diunduh pada 1 June 2021, dari https://www.medcom.id/ekonomi/makro/nbwlQwxk.

Nugroho, S. A., \& Firmansyah, A. (2017). Pengaruh financial distress, real earnings management dan corporate governance terhadap tax aggressiveness. Journal of Business Administration, $1(2), 17-36$.

Nurfauzi, R., \& Firmansyah, A. (2018). Managerial ability, management compensation, bankruptcy risk, tax aggressiveness. Media Riset Akuntansi, Auditing \& Informasi, 18(1), 75-100. https://doi.org/10.25105/mraai.v18i1.2775

Nurhandono, F., \& Firmansyah, A. (2017). Lindung nilai, financial leverage, manajemen laba dan agresivitas pajak. Jurnal Media Riset Akuntansi, Auditing \& Informasi, 17(1), 31-52.

OECD. (2020) Tax Administration: Privacy, Disclosure and fraud Risk Related to Covid-19.

Pajriyansyah, R., Firmansyah, A. (2017). Pengaruh leverage, kompensasi rugi fiskal dan 
manajemen laba terhadap penghindaran pajak. Keberlanjutan, 2(1), 431-459.

Peraturan Menteri Keuangan Republik Indonesia Nomor 23/PMK. 03/2020 Tentang Insentif Pajak Untuk Wajib Pajak Terdampak Wabah Virus Corona. Diakses dari https://jdih.kemenkeu.go.id/FullText/2020/23 PMK.03 2020Per.pdf

Peraturan Menteri Keuangan Republik Indonesia Nomor 44/PMK. 03/2020 Tentang Insentif Pajak Untuk Wajib Pajak Terdampak Pandemi Corona Virus Disease 2019. Diakses dari Https://Peraturan.Bpk.Go.Id/Home/Details/137005/Pmk-No-44pmk032020

Peraturan Menteri Keuangan Republik Indonesia Nomor 110/PMK. 03/2020 tentang Perubahan Atas Peraturan Menteri Keuangan Nomor 86/PMK.03/2020 Tentang Insentif Pajak Untuk Wajib Pajak Terdampak Pandemi Corona Virus Disease 2019. Diakses dari https://peraturan.bpk.go.id/Home/Details/144381/pmk-no-110pmk032020

Peraturan Pemerintah Pengganti Undang Undang Republik Indonesia Nomor 1 Tahun 2020 Tentang Kebijakan Keuangan Negara dan Stabilitas Sistem Keuangan Untuk Penanganan Pandemic Corona Virus Disease 2019 (COVID-19) dan/ atau Dalam Rangka Menghadapi Ancaman Yang Membahayakan Perekonomian Nasional dan/ atau Stabilitas Sistem Keuangan. Diakses dari https://peraturan.bpk.go.id/Home/Details/135060/perpu-no-1tahun-2020

Pipatnarapong, J., Beelitz, A., \& Jaafar, A. (2020). Tax avoidance and earnings management: accrual-based vs real-activity earnings management evidenced from BRICS. International Journal of Advanced Science and Technology, 29(7), 4800-4808.

Prasetia, T. E., Tommy,P., Saerang, I. S. (2014). Struktur modal, ukuran perusahaan dan risiko perusahaan terhadap nilai perusahaan otomotif yang terdaftar di BEI.Jurnal EMBA, 8792(2), 879-889.

Pratama, J. (2020). Pengaruh manajemen laba terhadap penghidaran pajak dengan kepemilikan asing sebagai pemoderasi. Skripsi: Fakultas Ekonomi dan Bisnis, Universitas Airlangga.

Rahma Nidya, I. (2020). 5 Upaya Pemerintah Kembalikan Pertumbuhan Perekonomian Nasional. KOMPAS.com. Diunduh 1 Juni 2021, dari https://nasional.kompas.com/read/2020/08/07/16224171/5.

Roychowdhury, S. (2006). Earning management through real activities manipulation. Journal of Accounting and Economics, 42, 335-370.

Saksessia, D., \& Firmansyah, A. (2020). The role of corporate governance on earnings quality from positive accounting theory framework. International Journal of Scientific and Technology Research, 9(1), 808-820.

Salim, S. (2015). Pengaruh leverage (DAR, DER, dan TIER) terhadap ROE perusahaan properti dan real estate yang terdaftar di BEI tahun 2010-2014. Jurnal Perbanas Review, 1 (November), $19-34$.

Sandy, S., \& Lukviarman, N. (2015). Pengaruh corporate governance terhadap tax avoidance: Studi empiris pada perusahaan manufaktur. Jurnal Akuntansi \& Auditing Indonesia, 19(2), 85-98. https://doi.org/10.20885/jaai.vol19.iss2.art1.

Saputra, M. F., Rifa, D., \& Rahmawati, N. (2015). Pengaruh corporate governance, profitabilitas dan karakter eksekutif terhadap tax avoidance pada perusahaan yang terdaftar di BEI. Jurnal Akuntansi \& Auditing Indonesia, 19(1), 1-12. https://doi.org/10.20885/jaai.vol19.iss1.art1.

Scott, W. R. (2015). Financial accounting theory seventh edition. Toronto: Pearson

Silaban, P., \& Siagian, H. L. (2020). Pengaruh penghindaran pajak dan profitabilitas terhadap nilai 


\section{1 | Bina Ekonomi}

perusahaan yang terlisting di BEI Periode 2017-2019. Jurnal Terapan Ilmu Manajemen Dan Bisnis, 3(2), 54-67.

Simamora, A. L. (2017). Pengaruh manajemen laba terhadap penghindaran pajak dimoderasi oleh political connection. Skripsi: Fakultas Ekonomi dan Bisnis, Universitas Diponegoro.

Siregar, S. V., \& Utama, S. (2008). Type of earnings management and the effect of ownership structure, firm size, and corporate-governance practices: Evidence from Indonesia. The International Journal of Accounting, 43(1), 1-27.

Suyanto, K. D., \& Supramono. (2012). Likuiditas, leverage, komisaris independen, dan manajemen laba terhadap agresivitas pajak perusahaan. Jurnal Keuangan Dan Perbankan, 16(2), 167177.

Tandean, V. A. (2016). Good corporate governance dan ukuran perusahaan pengaruhnya pada tax avoidance. Jurnal Ilmiah Akuntansi Dan Bisnis, 11(1), 54-62. https://doi.org/10.24843/jiab.2016.v11.i01.p07

Tiaras, I., \& Wijaya, H. (2015). Pengaruh likuiditas, leverage, manajemen laba, komisaris independen dan ukuran perusahaan terhadap agresivitas pajak. Jurnal Akuntansi, 19(3), 380-397. https://doi.org/10.24912/ja.v19i3.87.

Turyatini, T. (2017). The analysis of tax avoidance determinant on the property and real estate $\begin{array}{llll}\text { companies. Jurnal Dinamika Akuntansi, 143-153. } & \text { 9(2), }\end{array}$ https://doi.org/10.15294/jda.v9i2.10385.

Wang, S., \& Chen, S. (2012). The motivation for tax avoidance in earnings management. International Conference on Engineering and Business Management, 447-450

Zain, M.. (2008). Manajemen Perpajakan. Edisi 3. Jakarta: Salemba Empat.

Zang, A. Y. (2012). Evidence on the trade-off between real activities manipulation and accrualbased earnings management. Accounting Review, 87(2), 675-703. https://doi.org/10.2308/accr-10196

Zhao, C. X., Meng, L., Taylor, G., \& Richardson, G. (2020). Let's get connected: the effect of directors connected to a tax office on corporate tax avoidance in China. Journal of Accounting and Public Policy, 106817. https://doi.org/10.1016/j.jaccpubpol.2020.106817(n.d.). 